\title{
Evaluation of Effect of Distribution Strategy on Sale Promotion of Samsung Company in Iran
}

\author{
Mrs. Azadeh Kafaeipour \\ Industrial Management Institute, MBA, Marketing Branch, Tehran, Iran \\ Email: az.kafaeipour@gmail.com
}

\section{Doi:10.5901/mjss.2015.v6n6s2p733}

\section{Abstract}

\begin{abstract}
As a critical element of marketing, distribution is the method adopted in order to deliver products or services to the final customer or end-user via different distribution channels. The present study was formulated so as todeterminethe influence of distribution strategy on sale promotion of Samsung Company in Iranby use of two indices, i.e. stock and distribution channels. The data were collected by using a questionnaire. The statistical population was experts of production, sale, financial, and quality control sectors of Samsung Company in Iran. Validity and reliability of the questionnaire were approved by experts' confirmation and Cronbach's alpha, respectively. Data analysis was performed through descriptive statistics. The results acquired from the present study indicated that distribution strategy can have positive influence on sale promotion of Samsung Company in Iran if a careful attention is devoted to the management of stock and distribution channels.
\end{abstract}

Keywords: Sale promotion, distribution strategy, stock, distribution channels, Samsung, Iran.

\section{Introduction}

Distributionis an extremely importantcomponentin all marketing activities. It can be defined as an approachin order to deliver products or services to the finalconsumers via a variety of channels, known as distribution channels (Ulaga et al., 2002). In the present-day competitive world, different brands are taking every measure to not only keep their popularity in the market but promote the fame of their brand. Keller (2012) stated that distribution strategy as well as communication and pricing strategies can have varying effects on brands.

Place is defined as the point-of-sale, supplier, or provider where the product is obtained. Placecan also refer to where the behavior is practiced.Suppliers must be easily accessible to customers (Kotler, 2006). distribution can have effect on special value of brand and it can be used to enhance brand image among customers (Iranzadeh et al., 2012).

It is extremelychief activity to highlight the methods of finding the markets to find ways in order to sell your products and servicesin addition to where you can preserve your products and services, and the transportation of your stock (Gibson and Davidson, 2004).

Managers ought to consider marketing channels in order todeliver their products or services to the markets they are wishing. Managers have to cope with one of the most difficult phases of policymakingpracticebecausethe distribution channels they selectmight have a profound influence on other decisions about marketing. For example, what a company intends to do about having its pricing strategieshas a big deal to do withwhat kind of distribution channel is going to be adopted. Additionally, policies of a company about sale department as well as whatever strategies to elevate sale figuresare in a close contact withthe dedication and motivation provided forits staffs(Roosta et al., 2005).

In a research on the influence of distribution on brand special value, VanRiel et al. (2005) concluded that physical characteristics of products have considerable effect on brand special value. Managers frequently complain about a lack of communication between their marketing and sales executives, often caused by a poorly designed or implemented distribution channel strategy. A well-designed distribution channel strategy takes into account both the salespeople's activities with channel partners and the marketing managers' efforts to better reach and serve end-users.

Having proper strategies to manage and control distribution channelscan lead to formation of acomprehensivestructurefor having the most fruitful marketing activites, especially by considering distribution channels. That is, distribution is regarded asanassimilatedpart of every kind of marketing practice (Bakhtaeeand Golchinfar, 2010).The most significantresponsibility of all staffs in distribution departments, especially those who are in charge of management of distribution channels, is considering all aspects of distribution such as amount of the products or service, timing, and the final destination the intended product or service is going to be delivered (Esmaeelpoorand Ghaffari 
Ashtyani, 2002).Besides, having investments on anappropriate physical distribution and marketing system can be a very effective approach in order to increase sale figures in the current competitive market(Roosta et al., 2005).Distribution can be regarded aspractices by enterprises in order to deliver their services or products to customers (Kotler and Armstrong, 2008).

The present study aimed at evaluation of effect of distribution strategy on sale promotion of Samsung Company in Iran. The study tried to answer whether or not distribution strategy affects sale promotion of Samsung Company in Iran. Furthermore, two research questions were designed as follows:

$\mathrm{RQ}_{1}$ : Does stock influence on sale promotion of Samsung Company in Iran?

$\mathrm{RQ}_{2}$ : Do Distribution channels influence on sale promotion of Samsung Company in Iran?

\section{Methodology}

\subsection{Research method}

The investigationisregarded as anappliedresearchwith a descriptive approach. Additionally, it is considered to be a crosssectional study since it assessed the data obtained during an investigation in a given duration.

\subsection{Statistical Population}

Experts of Samsung Company in Iran in various parts of the company (i.e. manufacture, trade, commercial, and quality control)were regarded as the population. 208 people formed the population. Descriptive information onparticipants in the present study is summarized in Table 1.

Table 1: Descriptive information onparticipants(gender, age, level of education, years working in Samsung Co., total years working)

\begin{tabular}{llccc}
\hline & & Frequency & Percentage & $\begin{array}{c}\text { Cumulative } \\
\text { Percentage }\end{array}$ \\
Gender & Male & 192 & 92.3 & 92.3 \\
& Female & 16 & 7.7 & 100.00 \\
& $20-30$ & 36 & 17.3 & 17.3 \\
Age & $31-40$ & 132 & 63.5 & 80.8 \\
& $41-50$ & 36 & 17.3 & 98.1 \\
Level of & $>51$ & 4 & 1.9 & 100.00 \\
education & B.A or B.Sc. & 160 & 76.9 & 76.9 \\
Years & M.A. or M.Sc. & 48 & 23.1 & 100.00 \\
working in & 2-4 years & 40 & 19.2 & 19.2 \\
Samsung & 4-6 years & 48 & 23.1 & 42.3 \\
Co. & $>6$ years & 48 & 23.1 & 65.4 \\
Total years & 5-10 years & 72 & 34.6 & 100.00 \\
working & 10-15 years & 13 & 15.4 & 15.4 \\
& $>15$ years & 14 & 25.00 & 40.4 \\
\hline
\end{tabular}

Table 2 summarizes the descriptive data on participants of the present study from different parts of Samsung Co. As it can be seen, $30.8 \%$ of the participants were working in trade part of the company, $21.2 \%$ of them were in commercial part, $25.0 \%$ of them were in quality control part, and finally, $23.1 \%$ of the participants were in manufacture part.

Table 2: Descriptive data on participants of different parts

\begin{tabular}{lccc}
\hline Parts & Frequency & Percentage & Cumulative Percentage \\
Trade & 64 & 30.8 & 30.8 \\
Commercial & 44 & 21.2 & 51.9 \\
Quality control & 52 & 25.00 & 76.9 \\
Manufacture & 48 & 23.1 & 100.00 \\
Overall & 208 & 100.00 & - \\
\hline
\end{tabular}




\subsection{Questionnaire}

The questionnaire used in the present research was based upon a Likert range (very little, little, so-so, much, and very much). The questionnaire included two parts, i.e. general questions and sixparticular questions in order to find answers for the questions of this study. After analyzing the questionnaire, experts believed that the questionnaire is a valid tool to find answer for the research questions.Additionally, Cronbach's Alpha was calculated in order to make sure of reliability of the questionnaire. As the Cronbach's alpha was higher than 0.7 (0.83), the questionnaire was decided to be a reliable tool to find answers for the research questions.

\subsection{Statistical analysis}

Data analyses were performed by using descriptive analysis (calculation of frequency, percentage, mean values, standard deviation, median, and mode). The mean values were compared with each other to find the answers of the RQs. All the operations were performed in SPSS (version 22).

\section{Findings}

\section{$R Q_{1}$ : Does stock influence on sale promotion of Samsung Company in Iran?}

The results obtained from evaluation of effect of stock are summarized in Table 3. According to this table, over $80 \%$ of the participants considered stock availability in Samsung Co. as an important factor to improve the sales figure of the company. To top it off, near $90 \%$ of the participants in the present study considered that supervision on distribution agents of Samsung Co. is an important factor for promotion of sale figure in the market. However, only $17.30 \%$ of the participants stated that supervision on product delivery time can be regarded as very important factor to increase sale figures in Samsung Co.

Table 3: Evaluation of the effect of stock

\begin{tabular}{llcccccc}
\hline Questions & & Very little & little & So-so & Much & Very much & Mean \\
Stock availability in the & Frequency & 0 & 4 & 32 & 94 & 78 & 4.18 \\
company & percentage & 0 & 1.92 & 15.38 & 45.19 & 37.5 & \\
Supervision on distribution & Frequency & 0 & 3 & 21 & 88 & 96 & 4.33 \\
agents of the company & percentage & 0 & 1.44 & 10.09 & 42.30 & 46.15 & \\
Supervision on product & Frequency & 0 & 24 & 66 & 82 & 36 & 3.62 \\
delivery time & percentage & 0 & 11.53 & 31.73 & 39.42 & 17.30 & \\
Stock & Mean & 4.04 & & & & &
\end{tabular}

$R Q_{2}$ : Do Distribution channels influence on sale promotion of Samsung Company in Iran?

Table 4 summarizes the results acquired to answer the second RQ. According to this table, over $70 \%$ of the participants in the present study believed that sales offices in Samsung Co. are very important in increasing sale figures of the company in the market; however, around $20 \%$ of them believed that it has moderate effect to increase the sale of Samsung products.Approximately half of the participants in the present study believed that paying attention to distribution agents of Samsung Co. is very effective in increasing sale figures of this company. Furthermore, over $80 \%$ of the participants believed that having supervision on products delivery companies related to Samsung Co. is very important for sale promotion in the market.

Table 4: Evaluation of the effect of distribution channels

\begin{tabular}{|c|c|c|c|c|c|c|c|}
\hline Questions & & Very little & little & So-so & Much & Very much & Mean \\
\hline Sales offices of the company & Frequency percentage & $\begin{array}{c}2 \\
0.96\end{array}$ & $\begin{array}{c}11 \\
5.28\end{array}$ & $\begin{array}{c}42 \\
20.19\end{array}$ & $\begin{array}{c}81 \\
38.94\end{array}$ & $\begin{array}{c}72 \\
34.61\end{array}$ & 4.01 \\
\hline Distribution agents of the company & Frequency percentage & $\begin{array}{l}0 \\
0\end{array}$ & $\begin{array}{c}15 \\
7.21\end{array}$ & $\begin{array}{c}32 \\
15.38\end{array}$ & $\begin{array}{c}68 \\
32.69\end{array}$ & $\begin{array}{c}93 \\
44.71\end{array}$ & 4.14 \\
\hline Supervision on products delivery companies & Frequency percentage & $\begin{array}{l}0 \\
0\end{array}$ & $\begin{array}{c}7 \\
3.36\end{array}$ & $\begin{array}{c}31 \\
14.90\end{array}$ & $\begin{array}{c}103 \\
49.51\end{array}$ & $\begin{array}{c}67 \\
32.21\end{array}$ & 4.10 \\
\hline Distribution channels & Mean & 4.08 & & & & & \\
\hline
\end{tabular}


On the basis of the results obtained from analysis of the data, there is a very slight difference in terms of importance of stock and distribution attributes on sale promotion of Samsung Co. participants in the present study believed that supervision on distribution agents of the company is the most important factor in order to elevate the sale of the company whereas they considered supervision on product delivery time as the least important factor in increasing the sale figures of the company. According to the results, it can be claimed that both stock and distribution channels are important in increasing sale of Samsung $\mathrm{Co}$. and the company should pay attention to these two factors.

\section{Summary and Conclusions}

The present investigationwas formulated in order to assessdistribution strategy on sale elevation of Samsung Company in Iran. The subordinate hypotheses of the research (i.e. stock and distribution channels) hadmoretotalmark than the assumed score (i.e. 3) and consequently, they were accepted to put forthhelpfulinfluences on sale promotion. Consistent with the findings of the present study, it is suggested to ponder the subsequentguidelines to elevate the sale:

(1) Considering the distance from markets and finding solutions for ineffective and inefficient communications in distribution of the products;

(2) Preparation and educationcourses for deliverymediators and valuation of their performance;

(3) Gaining more knowledge on distribution system of target market and determination of fiscal resources, organization of qualified human force, and organization of facilities according to the relative regulations and available distribution channels;

(4) Grading and rating distribution agents so as tocreateenergy and cooperationamongst them;

(5) Running controlling measures on distributers and grading distribution channels on this basis;

(6) Recognition of various distribution channels such as chain stores, wholesale stores, retails stores, etc.;

(7) Precisemanagement on transport companies in order to provide more efficient services for customers;

(8) Evaluation of inclusive distribution methods or specific agencies in given areas;

(9) Preserving stock for management of market demand;

(10) Completing distribution process and considering all agreements according to which activities will be performed (Chaharbalesh, 2007).

One of the most important factors to be considered during designing distribution systems is the amount of purchase by final consumer. Other important factors include decision making priorities of consumer and customer, geographical distribution of customers, location of delivery, type of product, economical justification of distribution method, and potential limitations. Futureinvestigations are directed toward launching similar research in other home appliances and electronics companies and evaluation of effective factors on satisfaction and faithfulness of customers in other home appliances companies.

\section{References}

Bakhtaee A., Sh. Golchinfar (2010) management of distribution channels. Tadbir Journal. No. 179.

Chaharbalesh, M. (2007). Recognition of distribution systems and methods. Tadbir Journal, No. 186.

Esmaeelpoor H., p. GhaffariAshtyani (2002) Marketing. Islamic Azad University - Arak Branch

Gibson. C., D. Davidson (2004) Tamworth, Australia's 'country music capital': place marketing, rurality, and resident reactions. Journal of Rural Studies 20 (2004) 387-404

Hans M., F. Westerbeek, D. Shilbury (1999)Increasing the Focus on "Place" in the Marketing Mix for Facility Dependent Sport, Services Sport Management Review, 1999, 2, 1-23

Iranzadeh, S., Ranjbar, A., Poursadegh, N. (2012). Determination of effect of marketing mix on brand special value. Iranian Journal of Modern Marketing Research. Vol. 2, No 3(6), pp. 155-172.

Keller, K.L.(2012). Strategic Brand Management: Building, Measuring, and Managing Brand Equity. New Jersey:Prentice-Hall, 4thEd.

Kotler, P. (2006) marketing management; translation by Forouzandeh, B. Isfahan. Amoukhteh Publications.

Kotler, P., Armstrong, G.M. (2008). Principles of Marketing. Pearson/Prentice Hall, Ed. 12.

Roosta A., D. Venoos, A. Ebrahimi (2005) Marketing Management. Tehran. Samt Publications.

Ulaga W., A. Sharma, R. Krishnan (2002). Plant location and place marketing: understanding the process from the business customer's perspective. Industrial Marketing Management 31 (2002) 393- 401.

Van Riel, A.C.R., Mortanges, C.P., Streukens, S.(2005). Marketing antecedents of industrial brand equity: An empirical investigation in specialty chemicals. Industrial Marketing Management, 34, 841-847. 